\title{
Teaching for Social Reconstruction: The Nigerian Teacher in Perspective
}

\author{
Bakky Ngozi Adirika Ph.D \\ Department of Educational Foundations, Nnamdi Azikiwe University, \\ Awka, Anambra State, Nigeria
}

\section{Doi:10.5901/mjss.2014.v5n16p284}

\begin{abstract}
The Nigeria nation adopted education as an instrument for national development but seems to have largely ignored the view that no nation can rise above the quality of its teachers. Unfortunately, this stance, together with other apparent actions and inaction, resulting from conditions within the Nigerian society compound the problems of the teacher as he deals with his teaching chore. The paper calls on the Nigeria teacher to re-envision himself and his job so as to participate actively in reconstructing the Nigerian society against all odds.
\end{abstract}

\section{Introduction}

Teaching implies among other things the impartation of information, skills and attitudes so that others may learn. Teaching encompasses a variety of activities such as instructing, training, drilling, indoctrinating, initiating and schooling. While instruction could be seen as the process of building the knowledge of facts, relations or principles into the mind, training involves deliberately planned impartations of skills in the performance of an operation. Drilling, on the other land involves the repetition of simple knowledge, facts, skills or attitudes to a point where it can be done with minimal or no errors. Indoctrination is impartation in a way that is intentioned methodological, and consequence criterioned. It focuses one's mind to issue against which the mind has been indoctrinated. Initiation is the gradual opening of the mind to rules, regulations and practices believing that their internalization leads to the development of the mind. Schooling involves a process which is formally prescribed for the development of abilities, skills and talents in persons by exposing them to some predetermined curriculum. (Agwu, 2001).

All the activities and processes identified above require judgments and decisions which are crucial for the achievement of educational processes. One who must engage in making such judgments and decisions necessarily needs to be informed, exposed, accepted and indeed professional. This is because teaching by all its intend and purposes, is human development conscious, it is also very intensely concerned with the societal welfare as it is concerned with individual development. The arrangements, provisions, processes and activities which would lead to the acquisition of appropriate skills, attitudes, knowledge, ideas and appreciation should be painstakingly thought out and guided. The one to oversee these should also be very willing to engage and discharge them to the point of satisfaction.

Davis (2012) asserts that quality teaching needs qualified teachers to achieve quality outcomes. Bontick (2010) also posits that quality educational outcomes are directly related to quality teaching. The implication of the above assertions is that quality education cannot be left in the hands of mediocre. The teacher therefore, should be an adequately trained and skilled person. His role of transmitting to the present generation the accumulated knowledge and values of the past and the interpretation of the information with reference to the present and with a view to modifying and improving the future is quite demanding. He needs to possess an array of qualities that befit these professional needs.

The training given to teachers makes them to realize that success in teaching depends on a number of factors: the teachers' preparations before they enter the classrooms, how they present their materials, how they get on and about with their students, all affect the level of success they record; issues related to these may not be easily separated from the teacher personality. Teachers should therefore possess basic qualities in themselves that would enable them succeed as teachers.

Ogwa (2002) categorically stated that the competent teacher should be sensitive to the environment, master good teaching methods, desire to teach, possess the ability to develop good personal relationship as well as possess good knowledge of the subject matter he teaches. In other words, it is important that every good teacher should understand himself, be happy with himself, and display confidence in his actions and processes. Certain characteristics easily predispose him to required efficiency. A teacher should possess good character and should be morally strong to be able 
to mould the lives of others. If he is sincere and true in his words and actions, he serves as a model, consciously or unconsciously for his pupils. A teacher with a good sense of humour and care can easily install confidence in youngsters, their parents and colleagues. Trust is paramount in human relationships. A teacher who is not trusted on account of weak character would never really be trusted to work to an appreciable satisfaction level.

Competence in the handling of subjects is taking a new dimension in this age. As a result of knowledge explosions and the use of information communication technology, globalization and all their attendant changes, the teacher is becoming more of a facilitator of knowledge then its sole custodian. Emphasis is fast shifting from regurgitation of facts to discovery and construction of facts. The teacher stands among his students as a scholar himself, willing to add to his knowledge, whether the insight come from his pupils, technological gadgets or the environment. His open-mindedness grants a beautiful flexibility that makes him ready to receive new ideas, especially those that foster positive development. A sense of objectivity mingled with such flexibility enables the teacher to face reality without undue emotions and prejudices. His import is development - of both the individual and that of society.

Good teachers communicate freely and fluently(Ukeje, 1983). Discussion and dialogue are democratic principles they strive to impart in their students. A display of such principles by teachers themselves favourably dispose them to sharing thoughts, visions, insights, ideas, dreams for developmental purposes. They firmly express their views without being audacious; rather, with understanding and empathy they explain their views and generate the interest of others to their advantage. Clarity of thoughts and accuracy in their presentation are marks of outstanding teachers.

\section{The Nigerian Paradigm}

Ekpunobi (1996) gives an explanation of what the term "paradigm" represents. To him, a paradigm may be seen as a matrix of beliefs, patterns of conduct and bodies of knowledge, which interact to shape and define the conduct of inquiry. A paradigm prescribes problem fields for study as well as methods appropriate for their solution. The use of a particular paradigm tells scholars what to look for and what questions to concern themselves with as they study an event. In this particular paper, the concerns include some under girded sets of assumptions and an ideology that guide teachers in determining their role in the reconstruction of the Nigerian society.

The importance of education to the Nigeria society was captured in her National Policy on Education (FRN, 2004). The role of education in the Nigerian society is closely attached to national development. The governments' commitment to this belief also resulted in the federal government take cover of education at all levels and from all organizations in the 1980 s and later the invitation extended to private partners to involve in the Nigerian education system at the turn of the 21st century.

Several other activities allude to concern for quality education in order to enhance individual and societal development. Such include adjustments made in the educational structure, methods and contents, designed to meet the challenges of emerging economic and social structure dictated by globalization. In 1992, for instance, Nigeria adjusted her educational system for diversified curriculum. Vocational and technical emphases were included in order to empower individuals for self employment. (FRN,2004)

Curriculum is the vehicle through which education is attained. Success of implementation may closely relate to teacher issues earlier raised in this paper. Emeke \& Odetoyinbo (2004) point out that the national policy on education, with all her enunciated contents, levels, aims and objectives of education has all the necessary ingredients to land Nigeria into an advanced and developed society. Unfortunately, complaints about the educational system and its failure to transform Nigeria society abound.(Ogwa,2002).

Issues raised against the Nigerian educational system include that Nigeria inherited her educational system from her colonial masters. The English education system thrives today. The American system that was transported into the Nigerian education System, the 6334 system is serving America creditably yet; it seems that both have failed woefully in Nigeria. The theoretical orientation which runs through all levels of Nigerian formal education system encourage the production of half baked graduates who can hardly defend their certificates in practical situations. (Emeke and Odetoyinbo, 2004). Teaching and learning are carried out in non-conducive atmosphere while teachers are employed not on the basis of qualification but on utmost consideration of cost minimization.

Imagine where a teacher is employed to teach up to three subjects or worse still, when a chemistry teacher is made to teach all other science subjects like biology, physics, agriculture, mathematics and even additional mathematics. The menace seems more devastating in private schools where discipline, integrity and quality have been crucified at the altar of profit maximization (Davis, 2012).

Examination bodies collect money from candidates and expose questions to them before the examinations. Parents pay to miracle centres in order to get results for their children unjustly among other malpractices. Incessant 
battles rage between ASUU, other teaching associations and the Federal government because of educational implementation issues. There is thus much hue and cry on the need to transform the educational system because in the face of globalization, it is the economy that bears the brunt of the flaws in the educational system. (Davis, 2004). Should time and more resources continue to be wasted unjustifiably in Nigeria's system of education? There is need for teachers to act in order to rescue their career and job positions.

Ekpunobi (1996) is of the view that a social-anthropology approach could help to analyze how social phenomena and human behaviour deal with society. The social anthropology paradigm is primarily concerned with description and interpretation of issues to focus on the illumination and documentation of socially constructed realities.

Nigeria accepted education as an instrument for national development (FRN, 2004). The school is also seen as the central determinant of the future of the Nigerian Society by implication. If the Nigerian society is today looked upon as underdeveloped, corrupt, undisciplined, unpredictably chaotic, then there is a need for social reconstruction. Amidst several Boko Haram attacks, Nigerians want peace. Amidst several ethnic issues within her, she needs stability. Amidst scarcity of food and money, Nigerians need to eat to be healthy; they need to be healthy to be rich. People are running away from villages and many urban cities are overpopulated. The need for rural regeneration stares Nigeria in the face.

In an attempt to neglect cultural values and behavioural patterns, the need for cultural transformation becomes even more audacious (Broker and Lezzotes, 2007). There is need for true modernization, there is need for discipline, there is need to change vices and construct greater prospects. Where does the Nigerian teacher stand in all these?

If education unlocks the door to modernization, then the teacher holds the key. Teachers are foundation to quality in the schools. They should work against every weak foundation in the education sector. Every society has identifiable needs. Nigerian wants, needs, aspirations, desires and more are couched in her philosophy and educational goals. Education, a product of the society should reconstruct the society. Specific needs should be met in schools set up by the society to resolve societal needs (Agwu, 2001). Teachers are the main determinants of the role of the school. How effective are Nigerian teachers in these regards?

It is the teacher that pulls the school and the school in turn pulls the society. The quality of the teacher determines the quality of the society's workforce. (Bontick, 2010). Many buildings in Nigeria have collapsed because of the quality of teachers who produce the engineers. To change this kind of situation, changes should be effected first in the teachers themselves. Teachers, more than any other group in society, should be well educated, industrious, competent and disciplined.

There have been arguments that the teacher alone cannot be held responsible for the ripples in society. Broker \& Lezzottes (2007) assert that the major forces that cause students to fail in school lie within the students. Some have also argued that the school cannot be completely divorced from the society to which it forms part. They contend that the Nigerian schools are affected by all conditions in Nigeria not just by the quality of teachers in the schools.(Emeke and Odetoyinbo, 2004).

Another argument about teacher effectiveness in Nigeria focuses on the re-examination of assumptions related to teacher socialization, and development. Teacher socialization should incorporate some technical and professional subculture which all members of the group should possess (Ukeje, 1983). Teaching is a complex activity that makes a lot of demand on the professional. Like in other professions, a significant difference should exist in knowledge and state of performance of non professionals. Professionalism not only connotes knowledge, it also connotes a sense of mission, dedication and devotion. Professionals should be compassionate about what they do (Ukeje, 1983).

\section{Point of Departure}

Reconstructing is a mission that requires dedication and devotion (Ekpunobi, 1996). The Nigerian teacher needs a deep insight and an ability to analyze and reflect on the Nigerian society as it is presently. The right attitude for this is not the business as usual at all. A deep reflection on the status quo could give a clue on the way forward. Missionaries are propelled by convictions rather than pleasures. The compelling desire to effect changes in desirable direction is what the Nigerian teacher should be more concerned about. The realization that until this is done, nothing significant would happen, should keep the teacher's back turned against all vices in society. The need for the Nigeria teacher to stand out and reflect his mission and visions for a worthwhile Nigerian society is paramount.

Teachers can stand up against all imperfections that render them incapable of actualizing their missions. The position of ASUU in asserting the need for improved educational environment is commendable. The practice of divide and rule must never be allowed to thrive amidst Nigerian teachers. This is because; the same group of people that encourage the down play of the fight for a better life would be the same grouping of blame all teachers for not achieving a better life for and in society through their educational efforts. Holding tenaciously to issues that would enhance teacher 
performance must be the job of all teachers. No teacher should allow himself to be pulled out of a just cause for education.

It is also important to identify teachers who have the required sense of mission, devotion and dedication to deal with the chores of teaching. Beyond qualifications, a teacher needs commitment to perfect, sustain and excel in good teaching. A sense of mission predisposes a teacher to deliver within every setting using capability driven strategies that are consistent with deep insights and communication out-lays. A sense of mission and devotion makes a teacher to focus on motivating colleagues to develop and exhibits interest in innovations in spite of concomitant risks. Transformational leadership and followership engenders collaborative styles that clarify and continually define the purposes of teaching and learning in energized forms-thus making initiatives and innovations necessary for reconstruction and societal transformation.

A missionary is not quick at condemning traditions and culture. He rather investigates these as tools for effecting change. An ideal missionary, visionary and dedicated teacher, should be a fount of wisdom, showing interest in the society and its components, sieving out all that need to be changed, sustained or reconstructed. Altruistic service rather than pursuit of materials or economic gains are among his principles.

What makes it imperative for teachers and teachings to be properly undertaken are captured in Brembeck's (1966) observation as reported in Ekpunobi (1996). Education can kill or heal, build up or tear apart; lift up or deprave. Education is so powerful that it can make a mule dance. Much depends on the kind of education provided; who provides it, to whom it is provided, how it is provided, and who controls it. The power of education is immeasurable and teachers much not let diversionary measures to hijack the Nigerian education system.

The need to re-envision the Nigerian teacher cannot be over emphasized. It is only an alert and educated teacher that can ward off hijackers before they strike. Teacher education should consider social assumptions and consequences of professional learning and educate teachers appropriately (Ukeje,1983). Teachers that are educated, easily, through exposure, understand the reasons why they do what they do. It is this underlying knowledge that stands the good teacher out from other practitioners and makes him able to withstand other contrary socializing forces located in society and in the school. Functionality guides his priority selections and implementations. The era of atomization of teacher traits are fizzling out. The holistic perspective is preferred for teacher professional socialization in these changing times.

\section{The Way forward}

The Nigerian government should come open and sincere about what kind of educational outcomes she wants of her citizenry. Lip service, half measures, lukewarmness and business as usual in regard to education account for much of the nation's stultified development. Nigeria is still characterized by complex populations, high level of illiteracy, underdeveloped economy, religious fanaticism political affiliations and electoral malpractices. The government can help to checkmate these vices by nurturing a healthy workforce in the education industry. Government should not just rationalize and offer excuses for inadequacies in the education sector. They should rather provide for remarkable improvements through adequate and realistic budgeting for the education sector.

Government seems to be enjoying the wars raging between her and the Academic Staff Union of Universities (ASUU) and other academic associations on a regular basis in Nigeria. They arbitrarily seem to neglect agreements, breach contracts and damn the consequences. Threats and counter threats of educationalists, teachers and allied professions related to education runs contrary to all provisions made in the national policy document (FRN, 2004).

By accident or design the government is encouraging only the poorest of brains to join and stay in the teaching profession. Denial of reasonably substantial earning capacity and social mobility for all kinds of teachers is a screening device that keeps the best brains out of education. If this is allowed to continue, then one can say unequivocally that Nigeria really means to use education to deprive rather than build the Nigeria nation and her citizens.

\section{References}

Agwu, S. N. (2001). The teachers and the school curriculum, in Teaching in Nigeria: a dynamic approach, Enugu: Cheston Ltd.

Bontick, C. (2010). Poor Teachers, poor results. Retrieved October 30, 2012 from http://www.theaustralian.com.au/opinion/poorteachers-poor-result.

Broker, W. B. \& Lezzottes, L. (2007). Creating effective schools. Hollowness Brach, FL Learning Publication.

Davis, R. (2012). Limited teacher training, poor teaching quality:Early childhood parliament discussions ECI woes Retrieved November 19, 2012 from Jamaica.kdid.org/news/limited-teacher-training-poor-teaching-quality-earlychildhood parliament- discusses-eciwoes.

Ekpunobi, E. C. (1996). The role of the teacher in reconstructing the Nigerian society. An assessment of Prof B. O. Ukeje's paradigm 
Education and the Nigerian Society. Alice Ndu and B. C. Emenogu (eds), Awka, Meks Publisher Ltd.

Emeke, E. A. \& Odetoyinbo, B. (2004) Evaluation of teacher knowledge of the objectives of the Nigeria integrated science programme and implementation strategies: implication for pedagogical Practices. West African Journal of Education 24 (1) March, 2004. Federal Republic of Nigeria (2004). National Policy on Education. Abuja: NERDC Press.

Ogwa, C. E. (2002) Strategies for improving electronic instruction. Ebonyi State University Journal of Education 1 (1) 43-48.

Ukeje, B. O. (1983). Teacher Education for what? Fifth matriculation Address; College of Education Awka, February, 4. 